\title{
COPING STRATEGY PEKERJA KONTRAK DALAM MEMENUHI KEBUTUHAN DASAR DI PT. SANBE FARMA KOTA CIMAHI
}

\author{
St. Sarah Ramadhan \\ Politeknik Kesejahteraan Sosial Bandung, stsarahr@gmail.com \\ Lina Favourita Sutiaputri \\ Politeknik Kesejahteraan Sosial Bandung, linabangreng9@gmail.com \\ Wawan Heryana \\ Politeknik Kesejahteraan Sosial Bandung, wawan_heryana@poltekesos.ac.id
}

\begin{abstract}
Coping strategy of contract workers to fulfilling basic needs at PT. Sanbe Farma, Cimahi City, refers to the ability of contract workers to face pressure to fulfilling basic needs. This study aims to find out characteristics, self-activity, planning, self control, seeking instrumental support, seeking emotional support, acceptance and religiosity of contract workers to fulfilling basic needs. This study uses a quantitative approach with descriptive methods and uses a simple random sampling technique to 86 respondents. Data collection techniques use questionnaires, study documentation, observation and unstructured interviews. Test the validity of the measuring instrument using face validity and reliability testing using the alpha Cronbach method. This study was analyzed using quantitative analysis. The results showed that there were six aspects included in the high category, it has an average value of the actual score of all aspects is 274,25 of the ideal score of 344. This can be concluded that contract workers have been able to do coping strategies to fulfilling basic needs and needed an increse efforts to looking for instrumental social support. The recommendation program for this research namely "Instrumental Social Support for Contract Workers Program through the Company Level Workers Union (CLWU) at PT. Sanbe Farma, Cimahi City". The method used in the implementation of this program is the method of social group work with a series of activities that form self-help groups, Communication, Information and Education (IEC) activities, discuss and share experiences of contract workers. The program is expected to increase the instrumental social support of contract workers to fulfilling basic needs and overcome their problems.
\end{abstract}

Keywords:

Coping strategy; contract workers; basic needs; self help group.

\begin{abstract}
Abstrak
Coping strategy pekerja kontrak dalam memenuhi kebutuhan dasar di PT. Sanbe Farma Kota Cimahi merujuk pada kemampuan pekerja kontrak untuk menghadapi tekanan dalam pemenuhan kebutuhan dasar. Penelitian ini bertujuan untuk menggambarkan tentang karakteristik, keaktifan diri, perencanaan, kontrol diri, mencari dukungan yang bersifat instrumental, mencari dukungan yang bersifat emosional, penerimaan dan religiusitas pekerja kontrak dalam memenuhi kebutuhan dasar. Penelitian ini menggunakan pendekatan kuantitatif dengan metode deskriptif
\end{abstract}


dan menggunakan teknik simple random sampling kepada 86 responden. Teknik pengumpulan data menggunakan kuesioner, studi dokumentasi, observasi dan wawancara tidak terstruktur. Uji validitas alat ukur menggunakan validitas muka (face validity) dan uji reliabilitas menggunakan metode alpha cronbach. Penelitian ini dianalisis menggunakan analisa kuantitatif. Hasil penelitian menggambarkan bahwa terdapat enam aspek yang termasuk dalam kategori tinggi dengan nilai rata-rata skor aktual keseluruhan aspek adalah 274,25 dari skor ideal 344. Maka dapat disimpulkan bahwa pekerja kontrak sudah mampu melakukan coping strategy dalam memenuhi kebutuhan dasar dan diperlukan adanya peningkatan upaya mencari dukungan sosial bersifat instrumental. Rekomendasi program untuk pemecahan masalah yaitu "Program Peningkatan Dukungan Sosial Instrumental Pekerja Kontrak melalui Serikat Pekerja Tingkat Perusahaan (SPTP) di PT. Sanbe Farma Kota Cimahi”. Metode yang digunakan dalam pelaksanaan program ini adalah metode social group work dengan rangkaian kegiatan pembentukan kelompok bantu diri, kegiatan Komunikasi, Informasi dan Edukasi (KIE) serta diskusi dan berbagi pengalaman para pekerja kontrak. Program ini diharapkan dapat meningkatkan dukungan sosial instrumental pekerja kontrak dalam memenuhi kebutuhan dasar dan mengatasi masalah yang dialaminya.

Kata Kunci:

Coping strategy; pekerja kontrak; kebutuhan dasar; kelompok bantu diri. 


\section{PENDAHULUAN}

Indonesia merupakan salah satu negara dengan perkembangan industri cukup pesat dalam bidang yang sesuai dengan kebutuhan masyarakat. Perubahan lahan pertanian menjadi lahan industri menyebabkan dampak besar terhadap kehidupan masyarakat. Pergantian mata pencaharian penduduk dari petani menjadi pekerja atau buruh pabrik sudah tidak asing lagi terjadi. Penduduk usia produktif menjadi subjek penting dalam dunia kerja untuk memenuhi kebutuhan hidupnya dengan bekerja khususnya di bidang industri.

Manusia mempunyai kebutuhan yang sama atau berbeda dengan kebutuhan orang lain pada suatu ruang dan waktu tertentu. Kebutuhan-kebutuhan perlu dipenuhi untuk memelihara dan mengembangkan kehidupan manusia. Pemenuhan kebutuhan dasar merupakan kebutuhan individual yang sangat penting bagi kehidupan yang lebih baik. Apabila kebutuhan-kebutuhan tidak terpenuhi dengan baik, maka kemungkinan kehidupan manusia akan mengalami hambatan. Dengan arti lain, apabila kebutuhan tidak terpenuhi maka terjadilah masalah. Bekerja merupakan salah satu upaya yang dilakukan oleh banyak orang, karena jika seseorang bekerja ia akan memiliki pendapatan yang dapat digunakan untuk memenuhi kebutuhan dasarnya.

Bekerja menjadi buruh atau pekerja kontrak dalam suatu perusahaan menjadi salah satu pilihan untuk bertahan hidup. Pada saat ini semakin banyak perusahaan yang menggunakan sistem kerja kontrak. Menurut Undang-undang No. 13 Tahun 2003 tentang Ketenagakerjaan dalam Pasal 59 ayat 1: "Pengertian karyawan kontrak adalah karyawan yang bekerja pada suatu instansi dengan kerja waktu tertentu yang didasari atas suatu perjanjian atau kontrak dapat juga disebut dengan Perjanjian Kerja Waktu Tertentu (PKWT), yaitu perjanjian kerja yang didasarkan suatu jangka waktu yang diadakan untuk paling lama 2 (dua) tahun dan hanya dapat diperpanjang 1 kali untuk jangka waktu maksimal 1 (satu) tahun." Adanya sistem kerja kontrak ini membuat posisi pekerja/buruh menjadi semakin lemah karena tidak adanya kepastian kerja, kepastian upah, jaminan sosial, jaminan kesehatan, pesangon jika dilakukan PHK dan membuat pekerja tidak dihadapkan pada banyak pilihan kecuali dengan menerima kondisi yang ada.

\section{Menjalani ketidakpastian sebagai} pekerja kontrak akan menimbulkan resiko permasalahan yang berkaitan dengan pemenuhan kebutuhan dasar. Pekerja kontrak dituntut untuk dapat memiliki coping strategy yang baik dalam menyelesaikan permasalahan yang dihadapi. Coping strategy menurut Chaplin (2014) merupakan suatu tingkah laku dimana individu melakukan interaksi dengan lingkungan sekitarnya dengan tujuan menyelesaikan tugas atau masalah. Pengertian lain tentang koping menurut Lestari (2015) merupakan suatu usaha penyesuaian diri yang ditujukan pada sumber stres yang menimbulkan emosi-emosi tidak menyenangkan. Berdasarkan pengertian tersebut berarti bahwa setiap individu memiliki kemungkinan untuk memiliki konflik-konflik atau emosi yang tidak menyenangkan dan tuntutan lingkungan maupun internal yang membuat individu sangat penting untuk memiliki coping strategy yang baik dalam melakukan usaha pemecahan masalah yang dihadapinya.

Cohen dan Lazarus dalam Folkman (1984) menambahkan tujuan perilaku coping strategy yaitu untuk mengurangi kondisi lingkungan yang menyakitkan, menyesuaikan 
dengan peristiwa-peristiwa atau kenyataankenyataan yang negatif, mempertahankan keseimbangan emosi, mempertahankan selfimage yang positif, serta untuk meneruskan hubungan yang memuaskan dengan orang lain. Berdasarkan pada penjelasan tersebut, coping strategy dalam kehidupan seseorang harus mampu terjaga agar dapat dilaksanakan dengan baik selama ia melakukan kegiatan dan aktivitasnya sehari-hari. Hal tersebut juga berkaitan dengan pemenuhan kebutuhan dasar menurut Edi Suharto (1997:159) yang membagi kebutuhan menjadi 7 jenis, yaitu: kebutuhan fisik, kebutuhan psikologis, kebutuhan sosial, kebutuhan spiritual, kebutuhan ekonomi, kebutuhan pendidikan, dan kebutuhan keadilan.

Misi atau tujuan utama pekerjaan sosial berdasarkan NASW dalam Fahrudin (2012) adalah untuk meningkatkan kesejahteraan manusia (human well-being) dan membantu memenuhi kebutuhan-kebutuhan dasar manusia, dengan perhatian khusus pada kebutuhan-kebutuhan orang-orang rawan, tertindas dan miskin. Tujuan pekerja sosial oleh NASW adalah: (1) meningkatkan kemampuan-kemampuan orang untuk memecahkan masalah, mengatasi (coping), perkembangan; (2) Menghubungkan orang dengan sistem-sistem yang memberikan kepada mereka sumber-sumber, pelayananpelayanan dan kesempatan-kesempatan; (3) Memperbaiki keefektifan dan bekerjanya secara manusiawi dari sumber-sumber dan pelayanan-pelayanan; dan

Mengembangkan dan memperbaiki kebijakan sosial. Berdasarkan penjelasan tersebut, memiliki arti bahwa mengatasi suatu masalah atau mampu memiliki coping strategy yang baik merupakan salah satu tujuan dari pekerjaan sosial khususnya di bidang industri.
Berdasarkan proyeksi Badan Perencanaan Pembangunan Nasional (Bappenas) 2013, jumlah penduduk Indonesia pada tahun 2018 mencapai 265 juta jiwa. Jumlah tersebut terdiri dari 133,17 juta jiwa laki-laki dan 131,88 juta jiwa perempuan. Populasi kategori usia produktif rentang usia 14-64 tahun adalah 179,13 juta jiwa atau sebesar $67,6 \%$ dan penduduk usia lanjut sebanyak 85,89 juta jiwa yaitu sebesar 5,8\%. Rasio angka ketergantungan (usia produktif terhadap usia nonproduktif) sebesar 47,9\%, lebih rendah dari tahun sebelumnya yaitu sebesar $48,1 \%$ dan juga menurun dari posisi pada tahun 2010 yang mencapai 50,5\%.

Jawa Barat merupakan provinsi dengan luas wilayah mencapai 35.377,76 $\mathrm{km}^{2}$, memiliki sebanyak 33,16 juta jiwa penduduk usia produktif (15-64 tahun) dan 15,52 juta jiwa usia tidak produktif (0-14 tahun dan 65 tahun keatas). Angka tersebut didapatkan berdasarkan proyeksi pertumbuhan penduduk Indonesia tahun 2013 yang dilakukan oleh Badan Perencanaan Pembangunan, Badan Pusat Statistik dan United Population Fund. Dependency Ratio (angka ketergantungan) di Jawa Barat pada tahun 2018 sebesar 46,8\%, artinya bahwa setiap 100 orang usia produktif terdapat sekitar 47 orang usia tidak produktif yang menjadi tanggungan penduduk usia produktif. Pada tahun 2020, angka ketergantungan penduduk di Jawa Barat diprediksi akan menjadi 46,4\%. Berdasarkan persentase tersebut, menunjukkan bahwa beban tanggungan kelompok usia produktif untuk membiayai hidup penduduk kelompok usia tidak produktif mengalami penurunan.

Berdasarkan data Badan Pusat Statistik, pada tahun 2015 provinsi Jawa Barat memiliki $49,61 \%$ penduduk tenaga kerja formal. Persentase ini meningkat menjadi 51,36\% 
pada tahun 2016 dan kembali turun pada tahun berikutnya menjadi 50,22\%. Jika dilihat berdasarkan jenis kelamin, jumlah tenaga kerja di Provinsi Jawa Barat yaitu sebesar 45,66\% laki-laki dan $38,63 \%$ perempuan pada tahun 2017. Berdasarkan data tersebut, tergambarkan bahwa terdapat banyak pekerja sektor formal yang berada di Jawa Barat. Pekerja formal bekerja pada perusahaan atau lembaga yang dikelola oleh pihak swasta maupun negara.

PT. Sanbe Farma merupakan salah satu grup perusahaan yang mengembangkan formulasi, penjualan produk obat yang terdiri dari tiga lokasi perusahaan yang salah satunya berada di kota Cimahi, Jawa Barat. PT. Sanbe Farma Unit I yang dijadikan lokasi penelitian ini pada pelaksanaannya tidak terlepas dari peran pekerja kontrak dalam berbagai bidang pekerjaan. Berdasarkan data pekerja tahun 2018 di PT. Sanbe Farma Unit I terdapat sebanyak 601 pekerja kontrak dari jumlah total pekerja sebanyak 1013 pekerja. Banyaknya tenaga kerja kontrak yang di pekerjakan mengakibatkan adanya gesekan-gesekan yang menimbulkan berbagai permasalahan yang dialami karena berbagai perbedaan kebutuhan pekerja.

(2017) tentang coping strategy mengungkapkan bahwa coping strategy pekerja outsourcing merujuk kepada kemampuan pekerja dalam menghadapi tuntutan kebutuhan untuk memenuhi kebutuhan keluarga. Pada pelaksanaannya masih terdapat masalah yang dirasakan pekerja outsourcing yaitu kurangnya informasi yang diperoleh untuk membantu penyelesaian masalah, kurangnya pengetahuan untuk mengakses informasi lebih luas dan kurangnya transparansi perusahaan penyedia jasa terhadap hak-hak pekerja yang seharusnya mereka dapatkan. Penelitian lain tentang pekerja kontrak oleh Leonardo Imanuel Terok (2015) menjelaskan bahwa implementasi perlindungan hukum dan hak asasi manusia terhadap pekerja sudah tertera dalam UndangUndang Nomor 13 Tahun 2003 tentang Ketenagakerjaan, hak-hak yang didapatkan serta kewajiban yang harus dijalankan bukan hanya diperuntukan kepada pekerja saja namun juga kepada pihak-pihak yang terkait.

Selain itu, terdapat penelitian tentang coping strategy oleh Suryani (2006) menyimpulkan bahwa coping strategy informan dalam memecahkan masalah ekonomi keluarga yang dihadapi memanfaatkan aset kepemilikan, seperti mengembangkan keterampilan yang dimiliki, memanfaatkan sumber-sumber yang ada dilingkungan, serta memanfaatkan harta benda yang mereka miliki. Hasil penelitian tersebut sejalan dengan fakta yang ditemukan di PT. Sanbe Farma Kota Cimahi melalui observasi dan wawancara dengan pihak Human Resources Development (HRD) PT. Sanbe Farma. Hasil yang didapatkan adalah PT. Sanbe Farma Unit I memiliki 601 pekerja kontrak dari jumlah total pekerja sebanyak 1013 pekerja yang memiliki kewajiban dan hak-hak yang harus dipenuhi sesuai dengan Perjanjian Kerja Waktu Tertentu (PKWT). Pekerja kontrak di PT. Sanbe Farma tidak terlepas dari berbagai permasalahan yang dihadapi terutama yang berhubungan dengan pemenuhan kebutuhan dasar.

Beberapa isu terkait pemenuhan kebutuhan pekerja dalam suatu perusahaan seperti PT. Sanbe Farma yaitu tentang sistem perubahan kontrak kerja yang dinilai merugikan pekerja (tuntutan ini dilakukan sejak tahun 2014 hingga saat ini), struktur skala upah pekerja dan penolakan pengupahan 
memakai metode golongan, penerapan kebijakan Perda Kota Cimahi tentang penambahan $5 \%$ di atas UMK, serta pemenuhan kebutuhan pelayanan kesehatan. Isu permasalahan ini menjadikan adanya pelaksanaan perundingan Perjanjian Kerja Buruh (PKB) yang melibatkan perwakilan dari setiap PT. Sanbe Group dan menghasilkan beberapa kebijakan baru terkait dengan pemecahan masalah yang dihadapi pekerja. (Sumber: Koran Perjoeangan.com, terbit tanggal 30 April 201).

Berdasarkan pasal 50 ayat (2) Perda Nomor 16 tahun 2015 tentang Penyelenggaraan Ketenagakerjaan, sistem kontrak kerja dapat memicu timbulnya masalah lain. Kegelisahan pekerja di PT. Sanbe Farma pada setiap akhir masa kontraknya dapat menyebabkan situasi kurang menyenangkan. Sistem gaji pekerja kontrak biasanya diberikan sebesar UMR Kota Cimahi yaitu Rp. 2.678.028,45,- yang terkadang tidak dapat memenuhi untuk pemenuhan kebutuhan dasar, terutama bagi pekerja single income. Pemenuhan kebutuhan dasar pekerja tidak hanya untuk dirinya sendiri, namun masih ada keluarga yang harus dipenuhi kebutuhannya. Berbagai tekanan terhadap pemenuhan kebutuhan dasar dapat menyebabkan pekerja kontrak mengalami kondisi yang sulit.

Berdasarkan hasil riset yang telah dilakukan oleh Rumah Diah Pitaloka (RDP) pada tahun 2015 di wilayah padat industri, membuktikan bahwa upah/gaji yang diterima oleh pekerja kontrak masih berada di bawah angka Kebutuhan Hidup Layak (KHL). Hal ini dikarenakan sebagian pekerja di PT. Sanbe Farma adalah tulang punggung bagi keluarganya. Meskipun gaji yang didapat dirasa cukup untuk memenuhi kebutuhan dasar sehari-hari, namun mereka kesulitan untuk mempersiapkan tabungan bagi masa yang akan datang. Hal ini berkaitan dengan kelangsungan hidup jika suatu saat terjadi goncangan dalam kehidupan mereka. Kondisi yang sulit, khususnya untuk memenuhi kebutuhan dasar dapat menjadikan mereka rentan terhadap kemiskinan sehingga dapat menimbulkan berbagai permasalahan lain dalam kehidupannya.

Sebagian besar pekerja kontrak memiliki status sebagai pencari nafkah untuk memenuhi kebutuhan dasar baik bagi dirinya sendiri maupun bagi keluarganya. Mereka dituntut untuk mampu mengatasi setiap tuntutantuntutan yang dihadapi dalam pemenuhan kebutuhan dasar secara tepat agar terhindar dari situasi menekan dan menegangkan yang dapat menjadikan dirinya merasa stres. Pada saat itulah pekerja kontrak membutuhkan coping strategy yang tepat agar mampu bertahan dan mengatasi permasalahan yang dialami saat ini maupun di masa yang akan datang.

Perbedaan coping strategy yang dimiliki memungkinkan seseorang untuk melakukan hal berbeda dalam mencari solusi terhadap masalah yang dihadapi. Seperti yang dijelaskan oleh Titik Lestari (2015), bahwa cara individu menangani sesuatu yang mengandung tekanan ditentukan oleh sumber daya individu yang meliputi kesehatan fisik, keyakinan atau pandangan positif, keterampilan memecahkan masalah, keterampilan sosial, dukungan sosial dan materi. Coping strategy yang dimiliki pekerja kontrak yang baik dalam memecahkan masalahnya dapat menghindarkan dirinya dari emosi-emosi atau perilaku negatif seperti kecemasan, stress, burnout atau hal lain yang dapat menghambat pelaksanaan keberfungsian sosialnya. 
Carver (1989) menyebutkan bahwa aspek-aspek strategi coping ada tujuh aspek, antara lain: 1) Keaktifan diri, merupakan suatu tindakan untuk mencoba menghilangkan atau mengelabui penyebab stress atau memperbaiki akibatnya dengan secara langsung; 2) Perencanaan, adalah dengan memikirkan tentang bagaimana mengatasi penyebab stress antara lain dengan membuat strategi untuk bertindak, memikirkan tentang langkah upaya yang perlu diambil dalam menangani sesuatu masalah; 3) Kontrol diri, adalah cara individu untuk membatasi keterlibatannya dalam aktivitas kompetisi atau persaingan dan tidak bertindak terburu-buru; 4) Mencari dukungan sosial yang bersifat instrumental, antara lain nasihat, bantuan, atau informasi; 5) Mencari dukungan sosial yang bersifat emosional, antara lain dukungan moral, simpati atau pengertian; 6) Penerimaan, adalah sesuatu yang penuh dengan stress dan keadaan yang memaksanya untuk mengatasi masalah tersebut; dan 7) Religiusitas, adalah sikap individu menenangkan dan menyelesaikan masalah secara keagamaan.

Berdasarkan penjelasan menurut Carver, dapat dilihat bahwa aspek-aspek tersebut merupakan bentuk dari problem focused solving dan emotion focused solving yang dapat digunakan oleh pekerja kontrak dalam menghadapi permasalahan. Penelitian ini menggunakan ketujuh aspek yang telah dijelaskan oleh Carver. Aspek tersebut dapat menggambarkan bagaimana pekerja kontrak dapat melakukan upaya memaksimalkan coping strategy yang dimiliki dalam memenuhi kebutuhan dasar.

Berdasarkan keterkaitan konsep dan fenomena yang terjadi, penelitian ini menjadi penting agar dapat memperoleh solusi tentang bagaimana upaya coping strategy pekerja kontrak dalam menghadapi permasalahan khususnya dalam memenuhi kebutuhan dasar. Berbagai fenomena yang terjadi tentang permasalahan yang dialami oleh pekerja kontrak mendorong peneliti untuk mengetahui gambaran empirik mengenai bagaimana coping strategy pekerja kontrak dalam memenuhi kebutuhan dasar di PT. Sanbe Farma Kota Cimahi.

Secara khusus penelitian ini bertujuan untuk mengetahui lebih dalam gambaran tentang: 1) Karakteristik pekerja kontrak di PT. Sanbe Farma Kota Cimahi; 2) Keaktifan diri pekerja kontrak dalam memenuhi kebutuhan dasar; 3) Perencanaan pekerja kontrak dalam memenuhi kebutuhan dasar; 4) Kontrol diri pekerja kontrak dalam memenuhi kebutuhan dasar; 5) Upaya pekerja kontrak untuk mencari dukungan sosial bersifat instrumental dalam memenuhi kebutuhan dasar; 6) Upaya pekerja kontrak untuk mencari dukungan sosial bersifat emosional dalam memenuhi kebutuhan dasar; 7) Penerimaan pekerja kontrak dalam memenuhi kebutuhan dasar; dan 8) Religiusitas responden dalam memenuhi kebutuhan dasar.

Penelitian ini diharapkan mampu membantu pekerja kontrak dalam memahami bagaimana coping strategy yang dapat dilakukan dalam memecahkan masalah yang dihadapinya, terutama yang berhubungan dengan pemenuhan kebutuhan dasar. Hal ini dikarenakan setiap pekerja kontrak memiliki cara masing-masing dalam menghadapi permasalahan. Peneliti memiliki harapan besar bagi pekerja kontrak agar dapat melakukan coping strategy sesuai dengan kapasitasnya dalam menghadapi permasalahan. 


\section{METODE}

Penelitian tentang coping strategy pekerja kontrak dalam memenuhi kebutuhan dasar di PT. Sanbe Farma Kota Cimahi adalah untuk mendapatkan gambaran aspek-aspek yang berkenaan dengan karakteristik, keaktifan diri, perencanaan, kontrol diri, upaya mencari dukungan sosial yang bersifat instrumental, upaya mencari dukungan yang bersifat emosional, penerimaan dan religiusitas dalam memenuhi kebutuhan dasar. Penelitian ini dilakukan menggunakan pendekatan kuantitatif dengan metode deskriptif untuk dapat membuat deskripsi gambaran secara sistematis, faktual dan akurat mengenai fakta-fakta, sifat-sifat serta hubungan antar fenomena mengenai coping strategy pekerja kontrak dalam memenuhi kebutuhan dasar di PT. Sanbe Farma Kota Cimahi.

Penelitian dilaksanakan di PT. Sanbe Farma Kota Cimahi Provinsi Jawa Barat. PT. Sanbe Farma merupakan salah satu perusahaan farmasi terbesar di Indonesia yang memiliki beberapa unit kerja di Jawa Barat. Perusahaan ini memiliki tenaga kerja yang terdiri dari pekerja tetap dan pekerja kontrak. Populasi dalam penelitian ini adalah pekerja kontrak yang bekerja di PT. Sanbe Farma Kota Cimahi dengan jumlah 601 orang pekerja kontrak. Rumus Slovin digunakan jika jumlah populasi diketahui dengan pasti jumlahnya, tingkat kesalahan (sampling error) ditentukan sebesar $10 \%$, dengan rumus berikut:

$$
\mathbf{n}=\frac{\mathbf{N}}{\mathbf{1 + N}\left(\mathbf{e}^{2}\right)}
$$

Keterangan:

$\mathbf{n}$ : ukuran sampel

$\mathbf{N}$ : ukuran populasi e : batas ketelitian yang diinginkan atau persen kelonggaran ketidaktelitian (ditetapkan sebesar 10\%)

Maka hasil perhitungan yang diperoleh adalah:

$$
\begin{aligned}
& \mathrm{n}=\frac{601}{\frac{1+601(0,1)^{2}}{601}}=\frac{601}{1+601(0,01)} \\
& \mathrm{n}=\frac{\frac{65,73}{7,01}}{2}
\end{aligned}
$$

Berdasarkan perhitungan banyaknya sampel tersebut, maka ditetapkan jumlah sampel dalam penelitian ini adalah sebanyak 86 responden.

Teknik sampling yang dilakukan adalah teknik probability sampling. Probability sampling yang digunakan dalam penelitian ini adalah teknik simple random sampling. Penentuan sampel diundi dengan cara membuat kerangka sampling yang terdiri dari sejumlah 601 pekerja kontrak. Data pekerja kontrak kemudian diurutkan dengan nomor sesuai bidang atau jenis pekerjaan. Peneliti membuat koding dengan memilih nomor pekerja kontrak pada kelipatan 4 (empat) seperti 4, 8, 12, 16, 20, 24, 28 dan seterusnya kemudian diambil sejumlah 86 nomor pertama, sehingga nomor pekerja kontrak itulah yang dijadikan responden dalam penelitian ini. Setelah didapatkan sejumlah 86 nomor yang telah diurutkan, maka peneliti menyerahkan daftar urutan nomor responden kepada pihak Human Resources Development (HRD) PT. Sanbe Farma untuk mengisi instrumen penelitian tentang coping strategy pekerja kontrak dalam memenuhi kebutuhan dasar di PT. Sanbe Farma Kota Cimahi. 
Teknik pengumpulan data yang dilakukan pada penelitian ini menggunakan beberapa teknik, yaitu:

1) Teknik angket yang digunakan dalam penelitian ini yaitu pengumpulan data dalam bentuk kuesioner. Instrumen penelitian yang digunakan berpedoman pada instrumen tentang Coping Strategy dari Carver (1989) dan dikutip dari penelitian terdahulu tentang coping strategy pekerja outsourcing oleh Diamira tahun 2017, kemudian disesuaikan dengan fokus permasalahan penelitian. Instrumen penelitian ini disampaikan kepada responden yang menjadi sampel dalam penelitian, kemudian responden diminta untuk mengisi salah satu alternatif jawaban yang dipandang sesuai dengan coping strategy pekerja kontrak dalam memenuhi kebutuhan dasar.

2) Observasi; dilakukan untuk melihat secara langsung kegiatan pekerja kontrak selama melakukan pekerjaan ataupun aktivitas bersama rekan sejawatnya.

3) Studi Dokumentasi; Studi dokumentasi dalam penelitian ini yaitu menggunakan dan mempelajari dokumen yang ada dan dapat dijadikan sebagai sumber data yang dibutuhkan baik berupa arsip, laporanlaporan, foto-foto dan lain sebagainya. Informasi yang ingin diperoleh dari studi dokumentasi adalah mengenai gambaran lokasi penelitian dan mengenai aspekaspek dalam coping strategy pekerja kontak dalam memenuhi kebutuhan dasar di PT. Sanbe Farma Kota Cimahi.

4) Wawancara; Teknik wawancara yang dilakukan dalam penelitian ini menggunakan pengumpulan data yang dilakukan dengan mengajukan pertanyaan secara langsung kepada responden penelitian dan pihak HRD untuk memperkuat data yang telah dikumpulkan melalui angket. Wawancara yang dilakukan adalah wawancara tidak terstruktur, sehingga pertanyaan yang diajukan secara bebas dimana peneliti tidak menggunakan pedoman wawancara yang telah tersusun.

Penelitian ini dilakukan menggunakan teknik analisis data kuantitatif. Pengolahan dan analisa data dalam penelitian ini menggunakan program SPSS (Statistical Package for the Social Sciences). Agar data yang diperoleh dari hasil penelitian mudah dibaca dan dipahami serta dianalisis, maka data tersebut disusun dalam bentuk diagram frekuensi dari setiap jawaban responden. Alat ukur yang digunakan untuk mengetahui coping strategy pekerja kontrak dalam memenuhi kebutuhan dasar di PT. Sanbe Farma Kota Cimahi menggunakan rating scale. Variabel yang akan di ukur dalam penelitian ini adalah coping strategy.

Uji validitas yang digunakan dalam penelitian ini adalah face validity (validitas muka). Face validity yang dilakukan dalam penelitian adalah dengan cara mengkonsultasikan pekerja sosial profesional untuk mendapatkan penilaian dan persetujuan sehingga instrumen tersebut dikatakan valid dan dapat digunakan. Pengujian reliabilitas dengan metode cronbach alpha ini menggunakan Statistical Package for the Social Sciences (SPSS) 25. Pengujian reliabilitas mempertimbangkan koefisien reliabilitas menurut Balian (1989) dalam Soehartono (2015:86). Hasil yang didapatkan adalah 0,777 yang berarti bahwa item pernyataan pada instrumen pada penelitian ini 
dapat dikatakan cukup reliabel atau terpercaya sebagai alat pengumpul data dalam penelitian.

\section{HASIL PENELITIAN}

\section{Karakteristik responden}

Penelitian tentang coping strategy pekerja kontrak dalam memenuhi kebutuhan dasar di PT. Sanbe Farma Unit I Kota Cimahi dilakukan kepada 86 responden berdasarkan berbagai karakteristik telah disesuaikan dengan tujuan penelitian yang dilakukan. Pada penelitian ini, jumlah responden perempuan lebih banyak daripada jumlah responden lakilaki dengan jumlah 57 orang atau sebesar $66,28 \%$ dan jumlah responden laki-laki hanya sebesar 33,72\% yaitu sebanyak 29 orang. Hal ini menunjukkan bahwa upaya untuk memenuhi kebutuhan dasar merupakan tanggung jawab bagi setiap orang tanpa memandang gender. Responden tersebar pada seluruh bidang pekerjaan yang ada di PT. Sanbe Farma Kota Cimahi.

Responden didominasi oleh kelompok usia 18-24 tahun dengan jumlah 46 orang atau sebesar $53,49 \%$ yang berarti lebih dari setengah populasi responden merupakan pekerja kontrak usia dewasa awal. Dimana pada usia ini seseorang memiliki tanggung jawab baru untuk memenuhi kebutuhan dasarnya secara mandiri dan tidak bergantung kepada orang lain. Hal ini dapat menimbulkan berbagai respon yang berbeda sesuai dengan kesiapan dan kemampuan yang dimiliki. Pemeluk agama Islam menjadi mayoritas agama yang dianut oleh responden yaitu sebesar $87,21 \%$ dengan jumlah 75 orang.

Mayoritas responden memiliki latarbelakang pendidikan SMK dan Sarjana dengan jumlah yang sama yaitu masingmasing 38 orang atau sebesar 44,19\%. Pendidikan merupakan salah satu kebutuhan dasar responden yang memengaruhi pola pikir dan pengetahuannya dalam menyelesaikan masalah.

Responden memiliki penghasilan beragam setiap bulannya, diketahui bahwa mayoritas responden memiliki penghasilan pokok setiap bulan Rp. 2.000.001,00 - Rp. 3.000 .000 yaitu sebanyak 51 orang atau sebesar 59,30\%. Data tersebut menunjukkan bahwa penghasilan pokok responden sesuai dengan UMK Kota Cimahi yaitu sebesar Rp. 2.678.028,45. Jumlah penghasilan yang didapatkan oleh pekerja kontrak memengaruhi bagaimana kebutuhannya dapat terpenuhi atau tidak dapat terpenuhi sehingga akan menyebabkan kemungkinan adanya permasalahan yang dihadapi. Namun, berdasarkan hasil penelitian mayoritas responden tidak memiliki penghasilan tambahan atau sampingan, yaitu sebanyak 68 orang $(79,07 \%)$. Hal ini menggambarkan bahwa sebagian besar responden masih bergantung pada penghasilan pokok yang didapatkan dari perusahaan untuk memenuhi kebutuhan dasarnya.

Responden pada penelitian ini mayoritas belum memilki tanggungan, yaitu sebesar 59,30\% dengan jumlah 51 orang. Pemenuhan kebutuhan dasar bukan hanya secara fisik, tetapi psikologis yang dapat memengaruhi coping strategy yang dimiliki. Mayoritas responden belum menikah, yaitu sebanyak 66 orang atau sebesar 76,74\%. Status pernikahan responden memengaruhi kematangannya dalam melakukan pemecahan masalah pemenuhan kebutuhan dasar (coping strategy).

Responden dalam penelitian ini terbagi menjadi beberapa bagian wilayah tempat tinggal yaitu 47 orang responden atau sebanyak $54,65 \%$ tinggal di wilayah Kota 
Cimahi. Jarak tempat tinggal dengan lokasi tempat kerja akan berpengaruh terhadap pemenuhan kebutuhan dasar, karena adanya perbedaan biaya yang digunakan untuk biaya transportasi.

Berdasarkan lama kontrak kerja, jumlah terbanyak responden yaitu 28 orang atau sebesar $32,56 \%$ yang memiliki kontrak kerja 1-6 bulan kerja dan 27 orang atau sebesar $31,40 \%$ pada rentang waktu kontrak 31-36 bulan. Jumlah responden berdasarkan kontrak kerja yang sudah dijalani yang terbanyak yaitu 36 orang $(41,86 \%)$ yang sudah menjalani kontrak kerja selama 1-6 bulan kerja dan Jumlah paling sedikit yaitu 10 orang responden $(11,63 \%)$ yang telah menjalani masa kontrak kerja 19-24 bulan. Saat pekerja telah menyelesaikan kontrak kerjanya, maka pekerja menunggu selama satu bulan untuk mendapatkan keputusan dari perusahaan apakah ia akan dilanjutkan kontrak kerjanya, diberhentikan atau diangkat menjadi pekerja tetap. Dalam masa inilah coping strategy pekerja kontrak dalam pemenuhan kebutuhan dasar akan berbeda sesuai dengan kemampuan yang dimiliki. Pekerja bisa saja mencari pekerjaan ditempat lain atau menunggu hingga dihubungi oleh perusahaan yang berarti ia tidak bekerja sama sekali.

\section{Coping Strategy Pekerja Kontrak dalam Memenuhi Kebutuhan Dasar}

Coping strategy merupakan aktivitas yang dilakukan individu dalam bentuk kognitif dan perilaku, baik disadari maupun tidak sebagai usaha penyesuaian diri yang bertujuan untuk mengurangi kondisi lingkungan yang menyakitkan, menyesuaikan dengan peristiwa atau kenyataan yang negatif, mempertahankan keseimbangan emosi serta meneruskan hubungan yang baik dengan orang lain.
Coping strategy yang digunakan dalam penelitian ini terdiri dari tujuh aspek, yaitu keaktifan diri, perencanaan, kontrol diri, upaya mencari dukungan sosial yang bersifat instrumental, upaya mencari dukungan sosial yang bersifat emosional, penerimaan, dan religiusitas dalam memenuhi kebutuhan dasar.

Berdasarkan hasil penelitian yang telah dilakukan, maka peneliti mendapatkan gambaran kemampuan coping strategy responden dalam memenuhi kebutuhan dasar di PT. Sanbe Farma Kota Cimahi. Gambaran tersebut dapat dilihat pada Tabel 1. sebagai berikut:

Tabel 1. Nilai rata-rata skor aktual keseluruhan aspek coping strategy pekerja kontrak dalam memenuhi kebutuhan dasar

\begin{tabular}{|llrrc|}
\hline No & \multicolumn{1}{c}{ Aspek } & $\begin{array}{r}\text { Skor } \\
\text { Aktual }\end{array}$ & $\begin{array}{r}\text { Skor } \\
\text { Ideal }\end{array}$ & $\begin{array}{c}\text { Persen- } \\
\text { tase }\end{array}$ \\
\hline 1. & Keaktifan Diri & 276,00 & 344 & $80,23 \%$ \\
\hline 2. & Perencanaan & 270,00 & 344 & $78,49 \%$ \\
\hline 3. & Kontrol Diri & 285,43 & 344 & $82,97 \%$ \\
\hline 4. & $\begin{array}{l}\text { Dukungan } \\
\text { Sosial yang } \\
\text { Bersifat } \\
\text { Instrumental }\end{array}$ & 234,57 & 344 & $68,19 \%$ \\
\hline 5. & $\begin{array}{l}\text { Dukungan } \\
\text { Sosial yang }\end{array}$ & & & \\
& $\begin{array}{l}\text { Bersifat } \\
\text { Emosional }\end{array}$ & 268,86 & 344 & $78,16 \%$ \\
\hline 6. & Penerimaan & 284,43 & 344 & $82,68 \%$ \\
\hline 7. & Religiusitas & 300,43 & 344 & $87,33 \%$ \\
\hline & Rata-Rata & 274,25 & 344 & $79,72 \%$ \\
\hline
\end{tabular}

Pengelompokan hasil skor jawaban setiap pernyataan responden dalam penelitian ini dibuat menggunakan perhitungan dengan tahapan sebagai berikut:

Skor minimum : Nilai terendah $\mathrm{x}$ Jumlah Pernyataan $(1$ x $86=86)$

Skor maksimum : Nilai tertinggi $\mathrm{x}$ Jumlah responden $(4$ x $86=344)$

Range (R) : Total skor maksimum - total skor minimum $(344-86=258)$

Kategori/Kelas : :3 
Interval $(\boldsymbol{i}=\mathrm{R} / \mathrm{K}) \quad:(344-86) / 3=86$

Kategori kelas yang didapatkan yaitu:

$$
\begin{array}{ll}
86-172 & \text { : Rendah } \\
173-259 & \text { : Sedang } \\
260-346 & \text { : Tinggi }
\end{array}
$$

Berdasarkan hasil yang didapatkan berdasarkan kelas kategori yang telah dibuat, kategori coping strategy pekerja kontrak dalam memenuhi kebutuhan dasar di PT. Sanbe Farma Kota Cimahi dapat dilihat pada Gambar 1. sebagai berikut:

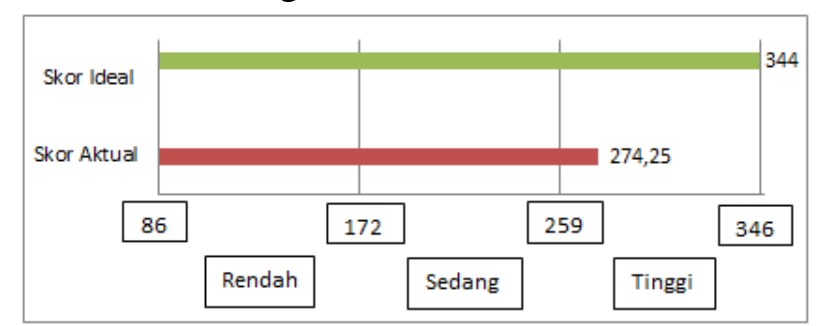

Gambar 1: Garis kontinum keseluruhan aspek coping strategy pekerja kontrak dalam memenuhi kebutuhan dasar di PT. Sanbe Farma kota Cimahi

Berdasarkan Tabel 1. coping strategy pekerja kontrak dalam memenuhi kebutuhan dasar di PT. Sanbe Farma Kota Cimahi berada pada kategori tinggi, yaitu 274,25 dari nilai ideal sebesar 344 atau mencapai angka $79,72 \%$. Hasil penelitian terhadap ketujuh aspek coping strategy adalah sebagai berikut:

Pertama adalah aspek keaktifan diri yang diteliti disesuaikan dengan tugas dan fungsi yang dijalankan oleh seorang pekerja kontrak. Berdasarkan ketujuh pernyataan tentang keaktifan diri, rata-rata skor aktual dalam kategori tinggi yaitu 276 dari skor ideal 344. Pekerja kontrak sudah mampu melakukan keaktifan diri dalam memenuhi kebutuhan dasarnya. Setiap pekerja kontrak sudah melaksanakan kewajiban sesuai dengan Perjanjian Kerja Waktu Tertentu (PKWT) sebagai pekerja kontrak di perusahaan dalam upaya untuk memenuhi kebutuhan dasar.
Kedua, aspek perencanaan yang diteliti mencakup perencanaan jangka panjang dan upaya perencanaan dalam penanganan masalah yang mungkin terjadi secara mendadak. Rekapitulasi skor jawaban responden pada aspek perencanaan memiliki nilai rata-rata skor aktual 270 dari skor ideal sebesar 344. Data tersebut menggambarkan bahwa perencanaan pekerja kontrak termasuk dalam kategori tinggi, berarti bahwa responden sudah mampu melakukan perencanaan dengan baik dalam coping strategy yang dilakukan dalam upaya perencanaan memenuhi kebutuhan dasar.

Aspek ketiga yaitu kontrol diri. Berdasarkan ketujuh pernyataan tentang kontrol diri, hasil rekapitulasi skor jawaban pada aspek kontrol diri termasuk ke dalam kategori tinggi, yaitu dengan nilai rata-rata sebesar 285,43 dari total skor ideal 344. Maka dari itu, dapat diambil kesimpulan bahwa coping strategy pekerja kontrak pada aspek kontrol diri sudah dilakukan dengan baik dan optimal dalam pelaksanaannya.

Aspek keempat yaitu upaya mencari dukungan social yang bersifat instrumental. Berdasarkan ketujuh pernyataan tentang upaya mencari dukungan sosial bersifat instrumental pada penelitian ini dapat diketahui total skor dari setiap pernyataan memiliki jumlah nilai yang berbeda. Diketahui bahwa rata-rata rekapitulasi skor hasil jawaban adalah 234,57 dan termasuk dalam kategori sedang. Pekerja kontrak cukup mampu mencari dukungan sosial yang bersifat instrumental dalam memenuhi kebutuhan dasar di PT. Sanbe Farma Kota Cimahi. Jika dibandingkan dengan beberapa aspek yang lain, nilai ratarata pada aspek ini merupakan nilai yang paling rendah. 
Aspek kelima yaitu mencari dukungan sosial yang bersifat emosional. Berdasarkan ketujuh pernyataan tentang aspek mencari dukungan sosial yang bersifat emosional, ratarata jumlah skor pada setiap pernyataan yaitu 268,86. Data ini menggambarkan bahwa pelaksanaan coping strategy pekerja kontrak dalam memenuhi kebutuhan dasar pada aspek mencari dukungan sosial yang bersifat emosional memiliki perbedaan sesuai dengan kemampuan coping strategy yang dimiliki. Coping strategy pekerja kontrak pada aspek mencari dukungan sosial yang bersifat emosional termasuk dalam kategori tinggi. Maka dapat disimpulkan bahwa pekerja kontrak telah mampu melakukan upaya untuk mencari dukungan sosial yang bersifat emosional dalam memenuhi kebutuhan dasarnya.

Aspek keenam yaitu penerimaan. Berdasarkan ketujuh pernyataan tentang aspek penerimaan pada penelitian coping strategy pekerja kontrak dalam memenuhi kebutuhan dasar di PT. Sanbe Farma Kota Cimahi, termasuk dalam kategori tinggi yaitu sebesar 284,43 dari skor total 344. Maka dari itu dapat disimpulkan bahwa pekerja kontrak sudah mampu melakukan penerimaan dalam memenuhi kebutuhan dasar di PT. Sanbe Farma Kota Cimahi.

Religiusitas merupakan aspek terakhir dalam penelitian coping strategy pekerja kontrak dalam memenuhi kebutuhan dasar di PT. Sanbe Farma Kota Cimahi. Berdasarkan ketujuh pernyataan tentang religiusitas pada penelitian ini, maka didapatkan rata-rata skor aktual adalah 300,43. Nilai tersebut menggambarkan bahwa pekerja kontrak telah mampu melakukan religiusitas dalam memenuhi kebutuhan dasanya. Hasil penelitian menggambarkan bahwa responden telah mampu melakukan coping strategy yang baik dalam memenuhi kebutuhan dasarnya. Namun upaya yang telah dilakukan oleh pekerja kontrak harus dapat dipertahankan atau lebih baik jika ditingkatkan agar mampu maksimal dalam melakukan coping strategy dalam memenuhi kebutuhan dasar.

\section{PEMBAHASAN}

Berdasarkan hasil penelitian yang dilakukan kepada 86 orang responden merupakan pekerja kontrak di PT. Sanbe Farma Kota Cimahi dengan berbagai karakteristiknya, coping strategy yang dimiliki pekerja kontrak dapat dikatakan sudah mampu dilaksanakan dengan baik terhadap pemenuhan kebutuhan dasarnya. Hal ini sesuai dengan hasil rekapitulasi skor jawaban pada setiap aspek yang menggambarkan bahwa enam dari tujuh aspek sudah mencapai kategori coping strategy yang tinggi. Sementara itu, hanya satu aspek yang berada pada kategori sedang.

Pekerja kontrak memiliki status sebagai pencari nafkah untuk memenuhi kebutuhan dasar baik bagi dirinya sendiri maupun bagi keluarganya. Kelompok usia pekerja kontrak menempati kelompok usia produktif, berarti bahwa mereka memiliki tanggung jawab untuk memenuhi kebutuhan dasar dengan bekerja. Setiap individu dituntut untuk mampu mengatasi setiap tuntutan-tuntutan yang dihadapi dalam pemenuhan kebutuhan dasar secara tepat agar terhindar dari situasi menekan dan menegangkan yang dapat menjadikan dirinya merasa stres. Pada saat itulah pekerja kontrak membutuhkan coping strategy yang tepat agar mampu bertahan dan mengatasi permasalahan yang dialami saat ini maupun di masa yang akan datang. Seperti yang dijelaskan oleh Folkman (1984) bahwa 
coping strategy merupakan suatu pola tingkah laku maupun pikiran-pikiran yang secara sadar digunakan untuk mengatasi tuntutan-tuntutan dalam situasi yang menekan dan menegangkan.

Setiap orang memiliki coping strategy yang berbeda dalam menghadapi permasalahannya. Perbedaan dapat dijadikan peluang untuk saling berbagi dengan sesama rekan pekerja kontrak tentang pemenuhan kebutuhan dasar sehari-hari. Perbedaan coping strategy yang dimiliki memungkinkan seseorang untuk melakukan hal berbeda dalam mencari solusi terhadap masalah yang dihadapi. Seperti yang dijelaskan oleh Titik Lestari (2015), bahwa cara individu menangani sesuatu yang mengandung tekanan ditentukan oleh sumber daya individu yang meliputi kesehatan fisik, keyakinan atau pandangan positif, keterampilan memecahkan masalah, keterampilan sosial, dukungan sosial dan materi.

\section{Keaktifan Diri Responden dalam Memenuhi Kebutuhan Dasar}

Aspek yang pertama yaitu keaktifan diri, menurut Carver (1989) yaitu suatu tindakan untuk mencoba menghilangkan atau mengelabui penyebab stres atau memperbaiki akibatnya secara langsung. Keaktifan diri responden masuk dalam kategori tinggi. Mayoritas pekerja kontrak merupakan usia dewasa awal yang telah mengalami banyak pengalaman hidup dan permasalahan khususnya pada pemenuhan kebutuhan dasar yang kemudian dapat dijadikan pelajaran sehingga bisa bersikap lebih dewasa dalam mencari jalan keluar lain saat menghadapi suatu permasalahan dalam hidupnya.

Keaktifan diri pekerja kontrak dalam memenuhi kebutuhan dasar ini berhubungan dengan bagaimana ia melakukan pekerjaan dengan baik di perusahaan tempatnya bekerja. Pekerja kontrak melakukan pekerjaan dengan tepat waktu, mengerjakan pekerjaan dengan bersungguh-sungguh dan berusaha untuk menghasilkan pekerjaan yang lebih baik. Tergambarkan juga bahwa pekerja kontrak menjalin relasi dengan orang lain untuk meningkatkan keaktifan dirinya, upaya ini dapat membantu mereka agar bisa melakukan tukar pengalaman tentang coping strategy yang dihadapi dalam memenuhi kebutuhan dasar.

Upaya meningkatkan potensi diri untuk menghasilkan pekerjaan yang lebih baik juga dilakukan oleh pekerja kontrak. Saat mereka mampu meningkatkan potensi dirinya, maka akan menjadikan peluang agar kontraknya bisa diperpanjang atau bahkan diangkat menjadi pekerja tetap di perusahaan. Dengan ini, maka pemenuhan kebutuhan dasar pekerja kontrak akan semakin membaik.

\section{Perencanaan Responden dalam Memenuhi Kebutuhan Dasar}

Dalam menghadapi situasi yang tidak menyenangkan, pekerja kontrak memerlukan upaya tepat dalam memenuhi kebutuhan dasarnya. Perencanaan merupakan upaya yang dilakukan seseorang dengan cara memikirkan atau menganalisa bagaimana strategi untuk mencari solusi antara lain tentang langkah upaya yang perlu diambil dalam menangani suatu masalah. Perencanaan yang baik akan menghasilkan pemecahan masalah yang baik pula.

Berdasarkan hasil penelitian, pekerja kontrak telah melakukan berbagai perencanaan dalam memenuhi kebutuhan dasarnya, seperti menyisihkan uang untuk membeli rumah pribadi, memiliki tabungan khusus untuk biaya kesehatan, pendidikan dan biaya tak terduga meskipun perusahaan telah 
menyediakan kesempatan bagi pekerja untuk mendaftarkan diri menjadi peserta BPJS Ketenagakerjaan dan BPJS Kesehatan pada saat pekerja telah diterima. Selain itu, tergambarkan bahwa pekerja kontrak membuat rencana pengeluaran setiap bulan. Perencanaan pengeluaran kebutuhan dasar yang dilakukan oleh pekerja kontrak ini dilakukan sebagai upaya untuk meminimalisir hambatan keuangan meskipun hanya bergantung pada gaji pokok saja. Perencanaan dalam menghadapi permasalahan merupakan salah satu coping strategy yang dilakukan oleh pekerja kontrak agar dapat mencari dan mempertimbangkan solusi yang terbaik berdasarkan pengalaman yang dimiliki. Terutama dalam pemenuhan kebutuhan dasar sehari-hari.

Aspek perencanaan yang dilakukan pekerja kontrak sudah termasuk dalam kategori tinggi. Hal ini menggambarkan bahwa sebagian besar pekerja kontrak sudah mampu melakukan perencanaan yang baik terhadap pemenuhan kebutuhan dasarnya. Coping strategy yang baik sangat diperlukan untuk bisa bertahan dalam situasi dan kondisi yang sesulit apapun.

\section{Kontrol Diri Responden dalam Memenuhi Kebutuhan Dasar}

Carver (1989) menjelaskan bahwa kontrol diri merupakan cara pekerja kontrak untuk menekan keterlibatan dari aktivitas yang kempetitif (suppression of competing activities) dalam memenuhi kebutuhan dasar. Aspek kontrol diri pekerja kontrak pada penelitian ini sudah termasuk dalam kategori yang tinggi, hal ini menggambarkan bahwa pekerja kontrak mampu melakukan upaya kontrol terhadap dirinya dalam kegiatan di tempat kerja maupun dalam memenuhi kebutuhan dasar dengan baik.
Upaya kontrol diri yang dilakukan pekerja kontrak yang utama adalah lebih mendahulukan kebutuhan dasar dibandingkan kebutuhan lainnya serta mempertimbangkan dengan baik pembelian suatu barang atau produk. Meskipun kebutuhan dasar setiap orang berbeda, pekerja kontrak meyakini bahwa kebutuhan dasar harus diupayakan terlebih dahulu agar dapat terpenuhi dibandingkan kebutuhan lain.

Kontrol diri pekerja kontrak dalam penelitian ini juga berkaitan dengan pekerjaan yang dilakukan. Pekerja kontrak berupaya untuk melakukan kontrol diri agar dapat selalu bekerja sesuai dengan prosedur yang telah disepakati bersama dengan pihak perusahaan. Upaya kontrol diri ini sangat diperlukan pekerja kontrak agar tidak memicu permasalahan yang tidak diinginkan dalam lingkungan pekerjaannya.

Upaya control diri yang baik dilakukan karena pekerja kontrak memiliki batas waktu kerja sehingga harus bisa melakukan kontrol diri dengan baik dalam pemenuhan kebutuhan dasar. Hal ini dilakukan agar tidak muncul hambatan dalam menjalankan pemenuhan kebutuhan dasar, terutama pada saat kontrak kerjanya telah mendekati batas waktu. Pekerja kontrak harus bisa melakukan banyak pertimbangan dalam melakukan suatu perbuatan yang akan memberikan dampak pada pemenuhan kebutuhan dasarnya.

Pekerja kontrak diharapkan melakukan banyak pertimbangan dalam melakukan suatu perbuatan yang akan memberikan dampak pada pemenuhan kebutuhan dasarnya. Kontrol diri yang dimiliki akan berpengaruh pada bagaimana ia mengambil keputusan dalam bertindak saat menentukan suatu pemecahan masalah terutama terhadap pemenuhan kebutuhan dasar. Meskipun pada 
pelaksanaannya, kontrol diri lebih mudah dilakukan terhadap diri sendiri dan bukan kepada orang lain. Maka dari itu, kontrol diri yang dilakukan harus mampu memengaruhi lingkungan agar dapat mendukung upayaupaya yang telah dilakukan dalam pemenuhan kebutuhan dasar.

\section{Upaya Responden untuk mencari Dukungan Sosial yang Bersifat Instrumental dalam Memenuhi Kebutuhan Dasar}

Aspek keempat yaitu mencari dukungan sosial yang bersifat instrumental, menurut Folkman dan Lazarus dalam Safaria (2009) upaya coping strategy instrumental berorientasi kepada pemecahan masalah. Mencari dukungan sosial yang bersifat instrumental yaitu mencoba untuk memperoleh informasi dari orang lain tentang permasalahan yang dihadapi. Mencari dukungan sosial yang bersifat instrumental antara lain dukungan yang diperoleh dari luar diri sendiri seperti bantuan, informasiinformasi dan nasihat yang dapat membantu dalam penyelesaian masalah khususnya pemenuhan kebutuhan dasar seorang pekerja kontrak. Aspek ini memiliki jumlah rata-rata nilai terkecil jika dibandingkan dengan aspek yang lain. Hal ini menggambarkan bahwa tidak semua orang bisa melakukan upaya mencari dukungan sosial yang bersifat instrumental dalam memenuhi kebutuhan dasar dengan baik. Kurangnya upaya yang dilakukan oleh pekerja kontrak untuk mencari informasi tentang strategi-strategi pemenuhan kebutuhan dasar menjadi salah satu permasalahan yang dihadapi.

Coping strategy pekerja kontrak dalam upaya mencari dukungan social yang bersifat instrumental ini sangat diperlukan terutama yang berkaitan dengan pekerjaannya. Salah satunya adalah upaya untuk mendapatkan informasi berupa pemotongan gaji, karena pekerja kontrak seharusnya dapat mengakses hal tersebut kepada bagian keuangan dan ini belum dapat dilakukan secara optimal. Upaya ini dilakukan agar pekerja bersikap aktif terhadap informasi yang terkait dengan pemenuhan kebutuhannya, yaitu pemberian gaji oleh perusahaan. Maka dari itu, pihak perusahaan dan pekerja harus menjalin komunikasi yang baik, terutama tentang pelayanan kepada pekerja kontrak.

Pekerja kontrak dalam penelitian ini tidak mampu optimal dalam mencari informasi tentang peminjaman uang atau bantuan instrumental lainnya jika tidak dapat memenuhi kebutuhan dasar secara mendadak. Hal ini dikarenakan pekerja kontrak lebih menarik diri dari orang lain karena merasa masih mampu untuk memenuhi kebutuhannya dengan resiko terjebak dalam permasalahannya sendiri. Kita ketahui bahwa tidak setiap saat pekerja kontrak berada dalam kondisi yang baik sehingga tetap membutuhkan bantuan dan informasi dari orang lain.

Pekerja kontrak dalam aspek ini sudah mampu mencoba melakukan upaya mencari peluang pekerjaan yang lebih baik dengan cara mencari informasi dan meminta bantuan teman agar dapat memberitahukan jika ada pekerjaan yang lebih baik. Pekerjaan yang lebih baik adalah pekerjaan yang bukan kontrak, sehingga responden bisa mendapatkan jaminan pekerjaan yang lebih pasti dengan fasilitas yang lebih terjamin.

Sebagian besar pekerja kontrak lebih memilih mencari informasi tentang cara yang tepat dan strategi yang mudah dalam pemenuhan kebutuhan dasar menggunakan media internet dibandingkan dengan media cetak. Hal ini dilakukan untuk menyesuaikan 
dengan perkembangan zaman. Namun, upaya ini perlu ditingkatkan lagi untuk menambah pengetahuan responden terhadap strategistrategi yang tepat dalam pemenuhan kebutuhan dasar. Hal ini dikarenakan tidak semua informasi yang bersumber dari internet sudah benar dan mudah dilakukan oleh semua orang, sehingga pekerja kontrak membutuhkan peran ahli dan kelompok untuk meningkatkan upaya ini.

Pekerja kontrak perlu meningkatkan upaya untuk mencari dukungan sosial yang bersifat instrumental dari manapun dan siapapun, tidak terbatas hanya kepada rekan kerja saja. Informasi-informasi terkait dengan permasalahan yang dihadapi seharusnya dapat diketahui oleh pekerja kontrak. Jika seseorang telah mengetahui banyak informasi tentang kemungkinan adanya masalah dalam dirinya, maka ia akan mempersiapkan diri dan mampu menghadapi permasalahan dengan lebih baik sehingga akan menemukan solusi terbaik seiring dengan berjalannya waktu.

Informasi-informasi yang didapatkan seharusnya bukan hanya didengar atau dibaca, tetapi harus dapat diterapkan dalam kehidupannya. Maka dari itu, upaya pekerja kontrak dalam mencari dukungan sosial yang bersifat instrumental perlu ditingkatkan agar dapat memahami dirinya dan potensi permasalahan yang akan dihadapi. Pekerja kontrak juga seharusnya dapat mengetahui pelayanan apa saja yang dapat di akses dalam membantu permasalahan pemenuhan kebutuhan dasar. Hal tersebut perlu dilakukan sebagai upaya untuk menjadikan coping strategy dalam memenuhi kebutuhan dasar lebih baik lagi.

\section{Upaya Responden untuk mencari Dukungan Sosial yang Bersifat Emosional dalam Memenuhi Kebutuhan Dasar}

Mencari dukungan sosial yang bersifat emosional merupakan suatu cara yang dilakukan oleh individu dalam menghadapi permasalahannya dengan cara mencari dukungan baik secara sosisal ataupun emosional pada keluarga, teman, bahkan lingkungan sekitar. Dukungan ini dapat berupa simpati, perhatian atau motivasi (Carver, 1989). Aspek ini menempati peringkat kedua terkecil setelah aspek mencari dukungan sosial yang bersifat instrumental. Jika dibandingkan dengan ketujuh aspek lainnya, hanya kedua aspek inilah yang lebih banyak melibatkan orang lain dalam pelaksanaannya.

Dalam aspek ini pekerja kontrak sudah melakukan upaya untuk berbicara dengan keluarga, teman kerja atau orang lain dalam menghadapi masalah yang ada. Pemenuhan kebutuhan dasar erat kaitannya dengan keluarga, maka dari itu upaya mencari dukungan sosial dari keluarga yang bersifat emosional dalam memenuhi kebutuhan dasar sangat diperlukan. Dukungan yang besar dari keluarga akan memengaruhi coping strategy seseorang dalam menghadapi permasalahan.

Dukungan sosial yang bersifat emosional tidak hanya didapatkan dari keluarga saja, tetapi bisa didapatkan dari teman kerja, orang yang memiliki banyak pengalaman hidup atau seorang profesional seperti pekerja sosial dan psikolog dapat memberikan banyak dukungan sosial secara emosional kepada pekerja kontrak dalam menghadapi masalahnya. Upaya ini dilakukan sehingga pekerja kontrak memiliki perasaan lebih tenang karena merasa ada 'teman' yang memiliki masalah sama seperti yang sedang ia hadapi. Hal ini juga dapat membuat pekerja 
kontrak lebih leluasa untuk menceritakan apa yang sedang dihadapi dan meminta saran terhadap penyelesaian masalahnya. Meskipun begitu, pekerja kontrak dalam penelitian ini belum mampu berusaha dengan baik untuk mencari dukungan sosial dalam permasalahan yang dihadapi.

\section{Penerimaan Responden dalam Memenuhi Kebutuhan Dasar}

Kedua aspek terakhir yaitu penerimaan dan religiusitas yang memiliki jumlah skor aktual yang paling tinggi jika dibandingkan dengan aspek lain. Penerimaan dalam penelitian ini yaitu strategi seseorang dalam menerima untuk menjalankan masalah yang dihadapinya dibarengi dengan upaya untuk memikirkan solusi yang terbaik. Aspek ini perlu dimiliki oleh pekerja kontrak agar dapat menerima keadaan yang dihadapi saat ini, maka jika hal ini telah dilakukan dengan baik ia akan dapat memikirkan jalan terbaik yang dapat dilakukan dalam memenuhi kebutuhan dasar.

Aspek penerimaan pekerja kontrak dalam memenuhi kebutuhan dasar erat kaitannya dengan pekerjaannya di perusahaan. Misalnya seperti sebagian besar responden telah menerima dengan baik bahwa pemotongan gaji untuk membayar asuransi kesehatan merupakan hal yang wajar dilakukan kepada pekerja. Asuransi kesehatan merupakan hal yang diperlukan bagi pekerja dan keluarganya. Maka dari itu, responden telah menerima dengan baik pemotongan gaji untuk pembayaran asuransi kesehatan secara otomatis setiap bulannya. Namun, berdasarkan penjelasan pihak HRD, pemotongan gaji ini disesuaikan dengan jenis pekerjaan dan jumlah upah yang didapatkan oleh pekerja kontrak sehingga tidak memberatkan dan tidak melakukan pemotongan pada gaji pokok yang diterima oleh pekerja. Pemotongan gaji yang dilakukan harus memiliki dasar yang jelas dan diinformasikan dengan baik kepada pekerja. Sehingga meskipun terdapat pemotongan gaji, pekerja tetap bisa memenuhi kebutuhan dasarnya sehari-hari.

Tergambarkan juga bahwa mayoritas pekerja kontrak menjawab telah menikmati pekerjaan yang sedang dijalani dan menerima status sebagai pencari nafkah bagi diri sendiri maupun keluarga. Hal ini dapat memengaruhi coping strategy pekerja kontrak agar dapat bekerja dengan baik sehingga dapat memenuhi kebutuhan dasarnya melalui upah yang didapatkan. Pekerja kontrak menerima bahwa setiap orang pasti pernah menghadapi permasalahan pada pemenuhan kebutuhan dasar sehingga sebagian besar merasa tidak khawatir terhadap masalah yang dihadapi karena yakin akan mampu menyelesaikannya. Pekerja kontrak meyakini bahwa kebutuhan dasar setiap orang pasti memiliki perbedaan, kebutuhan saat ini bisa saja berbeda dengan kebutuhan satu bulan yang akan datang. Maka dari itu, permasalahan dalam pemenuhan kebutuhan dasar mungkin saja terjadi. Penerimaan ini akan memunculkan coping strategy yang lebih baik. Saat ia sudah merasa bisa menyelesaikan permasalahan sebelumnya, ia akan merasa lebih tenang dalam menghadapi tantangan selanjutnya.

Perbedaan penerimaan terhadap permasalahan yang dihadapi dapat disebabkan oleh banyak faktor internal secara emosional maupun faktor eksternal. Hal ini dapat disebabkan oleh kedewasaan seseorang dalam memandang suatu permasalahan yang dihadapi. Rasa bersyukur dan bersabar terhadap keadaan yang dialami saat ini juga dapat memberikan rasa penerimaan yang tinggi pada diri pekerja kontrak. Pekerja 
kontrak yang telah memiliki penerimaan yang baik terhadap kondisi yang dialami saat ini akan menumbuhkan coping strategy yang baik dalam memenuhi kebutuhan dasarnya. Hal ini berarti bahwa responden dalam penelitian ini sudah mampu menerima apa yang terjadi pada dirinya dengan sangat baik.

\section{Religiusitas Responden dalam Memenuhi Kebutuhan Dasar}

Aspek religiusitas merupakan aspek yang memiliki skor rata-rata paling tinggi, berarti bahwa pekerja kontrak memiliki religiusitas yang baik dalam memandang permasalahan pemenuhan kebutuhan dasar yang dialaminya. Religiusitas merupakan upaya yang dilakukan individu untuk menangani permasalahan yang dihadapi dengan menenangkan diri dan menyelesaikannya secara keagamaan atau spiritulitas (Carver, 1989).

Aspek religiusitas ini menjadi bagian pelengkap dalam pelaksanaan coping strategy dalam memenuhi kebutuhan dasar. Religiusitas yang dimiliki pekerja kontrak tidak hanya berhubungan dengan kegiatan keagamaan yang dilakukan saja, melainkan bagaimana mereka dapat mengambil hikmah dari setiap kejadian untuk dijadikan pelajaran yang menjadikan dirinya lebih baik lagi dalam menghadapi tantangan hidup dimasa yang akan datang. Saat seseorang telah mampu mengambil hikmah dari setiap kesulitan yang dialami, maka individu tersebut kemungkinan besar akan lebih siap menghadapi berbagai permasalahan yang mungkin saja datang secara tiba-tiba. Coping strategy individu akan lebih baik saat ia mampu mengambil hikmah dari setiap pengalaman hidupnya. Hal ini dapat membantu orang tersebut untuk memahami setiap kondisi dan menentukan solusi terbaik dalam menyelesaikan permasalahannya. Mengambil hikmah dari setiap kejadian juga mampu membangun pemikiran atau pandangan positif terhadap suatu masalah. Hikmah tidak harus berawal dari permasalahan yang besar, namun setiap kejadian dalam hidup dapat diambil hikmahnya untuk memperbaiki coping strategy yang dimiliki.

Mendekatkan diri kepada Tuhan menjadi jalan yang dilakukan selain melakukan usaha-usaha untuk menyelesaikan masalah yang dihadapi. Religiusitas dalam coping strategy akan membatasi perilaku individu agar dapat menjalani proses pemecahan masalah dengan baik. Religiusitas mencegah individu untuk melakukan sesuatu yang dilarang oleh kepercayaannya, sehingga bisa membatasi perilaku pertahanan diri saat menghadapi permasalahan. Upaya yang dilakukan seperti mengikuti kegiatan keagamaan yang ada dilingkungan rumah maupun lingkungan pekerjaan yang akan menghasilkan banyak manfaat, seperti bertemu dengan tetangga sehingga bisa melakukan tukar pengalaman, mendapatkan ilmu yang bermanfaat, atau menumbuhkan ketenangan dalam dirinya.

Berdasarkan data yang telah didapatkan dalam penelitian ini, diketahui bahwa aspek terendah adalah upaya dalam mencari dukungan sosial yang bersifat instrumental. Aspek yang memiliki skor aktual paling rendah tersebut dapat dijadikan landasan untuk membuat usulan program peningkatan dukungan sosial yang bersifat instrumental kepada pekerja kontrak. Aspek tertinggi adalah religiusitas yang berarti dari aspek ini mampu menjadi landasan penting untuk membantu peningkatan aspek yang lain dalam memenuhi kebutuhan dasar. 
Sebagian besar responden lebih banyak menggunakan aspek-aspek yang dikelola oleh diri sendiri tanpa bantuan dari orang lain sebagai cara untuk menangani permasalahan yang dihadapi. Aspek yang digunakan seperti keaktifan diri, perencanaan, religiusitas, kontrol diri dan penerimaan. Kelima aspek tersebut dapat dilakukan oleh responden secara langsung untuk menghadapi permasalahan yang dihadapi. Sementara itu, kedua aspek lainnya yaitu mencari dukungan sosial yang bersifat instrumental dan emosional membutuhkan faktor eksternal dalam pelaksanaannya.

Melibatkan orang lain dalam penyelesaian masalah yang dihadapi belum mampu optimal dilakukan oleh pekerja kontrak. Tergambarkan bahwa dari setiap aspek penelitian ini, upaya coping strategy yang dilakukan oleh diri sendiri tanpa melibatkan dukungan orang lain memiliki nilai yang lebih tinggi. Kurang mampunya pekerja kontrak dalam kedua aspek ini dapat dijadikan pertimbangan usulan program dalam penelitian. Jika coping strategy dari diri sendiri sudah mampu dilakukan dengan baik, maka responden harus mampu meningkatkan coping strategy yang membutuhkan pihak lain dalam pelaksanaannya. Hal ini dapat berpengaruh terhadap pengambilan tindakan dalam penanganan masalah, karena sudah sewajarnya bahwa setiap manusia membutuhkan bantuan orang lain dalam bentuk moril maupun materiil dalam kehidupannya.

Pekerja kontrak perlu meningkatkan upaya untuk mencari dukungan sosial yang bersifat instrumental dari manapun dan siapapun. Permasalahannya adalah terkadang seseorang tidak menyadari bahwa ia sedang dihadapkan dengan masalah yang jika dibiarkan akan semakin parah. Informasiinformasi terkait dengan permasalahan yang dihadapi seharusnya dapat diketahui oleh pekerja kontrak. Jika seseorang telah mengetahui banyak informasi dan akses bantuan tentang kemungkinan adanya masalah dalam dirinya, maka ia akan mempersiapkan diri dan mampu menghadapi permasalahan dengan lebih baik sehingga akan menemukan solusi terbaik seiring dengan berjalannya waktu.

Berdasarkan hasil rekapitulasi skor aktual setiap aspek, diperoleh bahwa enam dari tujuh aspek coping strategy termasuk dalam kategori tinggi. Sementara itu, terdapat satu aspek yang termasuk dalam kategori sedang. Maka dari itu, kebutuhan dalam penelitian ini adalah meningkatkan kemampuan responden dalam mencari dukungan sosial yang bersifat instrumental. Berdasarkan permasalahan yang telah dijelaskan, peneliti mengidentifikasi beberapa kebutuhan yang dibutuhkan responden dalam mengatasi pemenuhan kebutuhan dasar dengan coping strategy yang dilakukan pekerja kontrak, yaitu:

1. Dukungan sosial informasi tentang strategi-strategi dalam pemenuhan kebutuhan dasar.

2. Dukungan informasi tentang pelayanan apa saja yang dapat diakses responden dalam mengatasi masalahnya.

3. Pengetahuan dan pemahaman tentang pemenuhan kebutuhan dasar.

Kebutuhan pekerja kontrak dalam mengatasi masalahnya memerlukan upaya diri sendiri agar dapat mencari informasi dan membuat suatu perencanaan masalahnya sendiri. Namun, diperlukan juga bantuan dari orang lain berupa dukungan sosial yang dapat 
memengaruhi coping strategy pekerja kontrak dalam memenuhi kebutuhan dasarnya. Pekerja kontrak harus mampu berjuang mengatasi masalah pemenuhan kebutuhan dasar dengan membuat rencana terbaik agar terhindar dari stres dan dapat mengurangi tekanan yang dirasakan. Upaya ini dilakukan sebagai pemecahan masalah terhadap pemenuhan kebutuhan dasar pekerja kontrak.

Pekerja kontrak membutuhkan bantuan dari banyak pihak dalam membantu mengatasi masalahnya, karena setiap manusia adalah makhluk sosial yang pasti membutuhkan orang lain dalam kehidupannya. Orang lain yang dapat memberikan dukungan sosial secara instrumental maupun emosional adalah orang-orang terdekat yang ada di lingkungan keluarga maupun lingkungan tempat kerja. Kebutuhan akan dukungan sosial yang bersifat instrumental harus disadari dan dipahami oleh pekerja kontrak agar mampu mempersiapkan dirinya dalam menghadapi permasalahan yang akan dihadapi.

\section{KESIMPULAN}

Manusia mempunyai kebutuhan yang sama atau berbeda dengan kebutuhan orang lain pada suatu ruang dan waktu tertentu. Pakar pekerjaan sosial, Johnson dalam Edi Suharto (1997:156) mendefinisikan kebutuhan adalah "that is which necessary for either in person or a social system to function within reasonable expectations, given the situation that exist" yang artinya "sesuatu yang penting untuk setiap orang atau sistem sosial yang berfungsi sebagai harapan yang layak, dari situasi yang ada." Kebutuhan berhubungan dengan harapan, dimana adanya harapan membuat kebutuhan ada dalam diri setiap orang yang harus terpenuhi dalam situasi tertentu. Harapan yang tidak dibarengi dengan kebutuhan akan menimbulkan masalah karena adanya kesenjangan. Pemenuhan kebutuhan dasar merupakan kebutuhan individual yang sangat penting bagi kehidupan yang lebih baik. Apabila kebutuhan-kebutuhan tidak terpenuhi dengan baik, maka kemungkinan kehidupan manusia akan mengalami hambatan. Dengan arti lain, apabila kebutuhan tidak terpenuhi maka terjadilah masalah.

Bekerja menjadi buruh atau pekerja kontrak dalam suatu perusahaan menjadi salah satu pilihan untuk bertahan hidup. Menurut Undang-undang No. 13 Tahun 2003 tentang Ketenagakerjaan dalam Pasal 59 ayat 1: "Pengertian karyawan kontrak adalah karyawan yang bekerja pada suatu instansi dengan kerja waktu tertentu yang didasari atas suatu perjanjian atau kontrak dapat juga disebut dengan Perjanjian Kerja Waktu Tertentu (PKWT), yaitu perjanjian kerja yang didasarkan suatu jangka waktu yang diadakan untuk paling lama 2 (dua) tahun dan hanya dapat diperpanjang 1 kali untuk jangka waktu maksimal 1 (satu) tahun." Pada saat ini semakin banyak perusahaan yang menggunakan sistem kerja kontrak. Adanya sistem kerja kontrak ini membuat posisi pekerja/buruh menjadi semakin lemah karena tidak adanya kepastian kerja, kepastian upah, jaminan sosial, jaminan kesehatan, pesangon jika dilakukan PHK dan membuat pekerja tidak dihadapkan pada banyak pilihan kecuali dengan menerima kondisi yang ada.

Pekerja kontrak dituntut agar dapat beradaptasi dengan memiliki coping strategy yang baik untuk memenuhi kebutuhan dasarnya dalam menghadapi situasi atau kondisi yang sulit. Coping strategy yang dimiliki pekerja kontrak yang baik dalam memecahkan masalahnya dapat menghindarkan dirinya dari emosi-emosi atau 
perilaku negatif seperti kecemasan, stress, burnout atau hal lain yang dapat menghambat pelaksanaan keberfungsian sosialnya. Coping strategy menurut Folkman (1984) adalah suatu pola tingkah laku maupun pikiran-pikiran yang secara sadar digunakan untuk mengatasi tuntutan-tuntutan dalam situasi yang menekan dan menegangkan.

Coping strategy yang dimiliki setiap orang memiliki perbedaan yang dipengaruhi oleh berbagai faktor penyebab. Begitu juga dengan pekerja kontrak, permasalahan yang dihadapi seperti pemenuhan kebutuhan dasar memerlukan penanganan yang berbeda. Coping strategy yang digunakan dalam penelitian ini terdiri dari tujuh aspek menurut Carver (1989), yaitu keaktifan diri, perencanaan, kontrol diri, upaya mencari dukungan sosial yang bersifat instrumental, upaya mencari dukungan sosial yang bersifat emosional, penerimaan, dan religiusitas dalam memenuhi kebutuhan dasar disesuaikan dengan tugas dan fungsi yang dijalankan oleh seorang pekerja kontrak.

Berdasarkan konsep tersebut penelitian ini dilakukan terhadap 86 responden dan diperoleh hasil penelitian yang terdiri dari karakteristik responden dan coping strategy responden dalam memenuhi kebutuhan dasar yang ditinjau dari tujuh aspek. Berdasarkan hasil penelitian, mayoritas responden dalam penelitian ini adalah perempuan, yaitu sejumlah 66,28\% (57 orang). Responden mayoritas merupakan usia 18-24 tahun dengan jumlah 46 orang atau sebesar 53,49\% yang sebagian besar merupakan pemeluk agama Islam. Responden dalam penelitian ini lebih banyak merupakan lulusan SMK dan sarjana dengan jumlah masing-masing $44,19 \%$. Penghasilan pokok responden mayoritas berada pada rentang Rp. 2.000.0001,00 - Rp.
3.000.000,00 dan tidak memiliki penghasilan tambahan setiap bulannya.

Responden pada penelitian ini sebanyak $76,74 \%$ belum menikah dan didominasi dengan responden yang belum memiliki tanggungan dalam keluarganya. Responden sebagian besar berdomisili di wilayah Cimahi, yaitu sebanyak 47 orang atau 54,65\% dengan jenis pekerjaan yang berbeda. Responden dalam penelitian ini merupakan pekerja yang dikontrak oleh perusahaan dengan jumlah terbanyak pada waktu 1-6 bulan kerja, yaitu sebesar 32,56\% dan sebagian besar telah menjalani 1-6 bulan kerja, yaitu sebanyak 36 orang atau sebesar $41,86 \%$.

Hasil penelitian coping strategy pekerja kontrak dalam memenuhi kebutuhan dasar di PT. Sanbe Farma Kota Cimahi ini termasuk dalam kategori tinggi dengan nilai rata-rata 274,25 dari nilai ideal 344, sehingga dapat disimpulkan bahwa responden telah mampu melakukan coping strategy dalam memenuhi kebutuhan dasarnya. Hal ini terbukti dengan enam dari tujuh aspek dalam penelitian ini, yaitu kontrol diri, perencanaan, keakifan diri, upaya mencari dukungan sosial bersifat emosional, penerimaan dan religiusitas termasuk dalam kategori tinggi. Sementara itu, hanya satu aspek mencari dukungan sosial yang bersifat instrumental berada dalam kategori sedang dengan nilai rata-rata skor aktual yang didapatkan adalah 234,57 dari skor ideal 344.

Berdasarkan data yang telah didapatkan dalam penelitian ini, diketahui bahwa aspek terendah adalah upaya dalam mencari dukungan sosial yang bersifat instrumental. Aspek tertinggi adalah religiusitas yang berarti dari aspek ini mampu menjadi landasan penting untuk membantu peningkatan aspek yang lain dalam memenuhi kebutuhan dasar. 
Sebagian besar responden lebih banyak menggunakan aspek-aspek yang dikelola oleh diri sendiri tanpa bantuan dari orang lain sebagai cara untuk menangani permasalahan yang dihadapi.

Kebutuhan yang pertama bagi pekerja kontrak adalah kebutuhan akan pengetahuan dan pemahaman tentang pemenuhan kebutuhan dasar. Kebutuhan akan dukungan sosial yang bersifat informasi membutuhkan kehadiran orang lain dalam pelaksanaannya. Dukungan sosial bersifat instrumental ini ditekankan kepada upaya pemberian informasi-informasi yang dapat membantu pemecahan masalah yang dihadapi. Informasi yang dibutuhkan pekerja kontrak terkait dengan permasalahan pemenuhan kebutuhan dasar yang dihadapi seharusnya dapat diakses dengan mudah. Permasalahannya adalah pekerja kontrak biasanya acuh dengan hal tersebut, mereka menganggap bahwa dirinya baik-baik saja dengan kondisinya saat ini. Sehingga diperlukan pemberian pengetahuan dan pemahaman tentang pemenuhan kebutuhan dasar bagi pekerja kontrak.

Kebutuhan yang kedua yaitu penguatan dan pemberian informasi tentang strategistrategi yang tepat dalam pemenuhan kebutuhan dasar dan pemecahan masalah lainnya. Dapat kita ketahui bahwa dengan menyandang status sebagai pekerja kontrak berarti bahwa ia tidak dapat menjamin akan terus memiliki pemasukan untuk memenuhi kebutuhan dasarnya. Hal ini karena saat pekerja telah menyelesaikan masa kontraknya, ia belum bisa memastikan apakah kontraknya akan diperpanjang atau malah diberhentikan dari perusahaan. Keadaan seperti ini akan menimbulkan kecemasan dan munculnya masalah baru seperti pengangguran jika ia tidak mempersiapkan rencana yang baik saat kontrak kerjanya berakhir. Sebagai upaya mempersiapkan diri, diperlukan informasi tentang strategi-strategi yang harus dimiliki oleh seorang pekerja kontrak, baik dalam pemenuhan kebutuhan dasar maupun mempersiapkan keberlanjutan karirnya.

Kebutuhan yang ketiga yaitu informasi tentang pelayanan apa saja yang dapat diakses pekerja kontrak dalam mengatasi permasalahan yang dihadapi. Dukungan sosial yang bersifat instrumental terdiri dari bantuan informasi terhadap penyelesaian masalah yang dihadapi. Bantuan informasi ini merupakan pelayanan apa saja yang bisa diakses, seperti informasi tentang asuransi pendidikan, lembaga atau individu profesional yang mampu memberikan bantuan dalam mengatasi masalah (misalnya pekerja sosial, psikolog, ahli ekonomi dan lainnya), koperasi bagi pekerja atau lembaga keuangan untuk menyimpan tabungan dengan aman.

Berbagai informasi yang dibutuhkan oleh pekerja kontrak seharusnya dapat diakses dengan baik, sehingga ia mampu mengatasi permasalahan yang dihadapi dengan solusi terbaik sesuai dengan kemampuannya. Upaya ini juga harus didasari oleh keinginan akan perubahan yang lebih baik dari diri pekerja kontrak itu sendiri. Pekerja kontrak harus mampu menggunakan coping strategy-nya dengan baik saat menghadapi permasalahanpermasalahan yang dialami. Gaya coping yang biasa dipakai seseorang dalam kehidupan sehari-hari dan kepribadian orang tersebut merupakan faktor internal yang memengaruhi seseorang dalam menentukan coping strategynya (Lazarus dalam Safaria, 2012).

Pekerja kontrak perlu meningkatkan upaya untuk mencari dukungan sosial yang bersifat instrumental dari manapun dan siapapun. Permasalahannya adalah terkadang 
seseorang tidak menyadari bahwa ia sedang dihadapkan dengan masalah yang jika dibiarkan akan semakin parah. Informasiinformasi terkait dengan permasalahan yang dihadapi seharusnya dapat diketahui oleh pekerja kontrak. Jika seseorang telah mengetahui banyak informasi tentang kemungkinan adanya masalah dalam dirinya, maka ia akan mempersiapkan diri dan mampu menghadapi permasalahan dengan lebih baik sehingga akan menemukan solusi terbaik seiring dengan berjalannya waktu.

Kebutuhan pekerja kontrak dalam mengatasi masalahnya memerlukan upaya diri sendiri agar dapat mencari informasi dan membuat suatu perencanaan masalahnya sendiri. Namun, diperlukan juga bantuan dari orang lain berupa dukungan sosial yang dapat memengaruhi coping strategy pekerja kontrak dalam memenuhi kebutuhan dasarnya. Pekerja kontrak harus mampu berjuang mengatasi masalah pemenuhan kebutuhan dasar dengan membuat rencana terbaik agar terhindar dari stres dan dapat mengurangi tekanan yang dirasakan. Upaya ini dilakukan sebagai pemecahan masalah terhadap pemenuhan kebutuhan dasar pekerja kontrak.

Pekerja kontrak membutuhkan banyak pihak dalam membantu mengatasi masalahnya, karena setiap manusia adalah makhluk sosial yang pasti membutuhkan orang lain dalam kehidupannya. Orang lain yang dapat memberikan dukungan sosial secara instrumental maupun emosional adalah orang-orang terdekat yang ada di lingkungan keluarga maupun lingkungan tempat kerja. Kebutuhan akan dukungan sosial yang bersifat instrumental harus disadari dan dipahami oleh pekerja kontrak agar mampu mempersiapkan dirinya dalam menghadapi permasalahan yang akan dihadapi.
Hasil penelitian ini sejalan dengan penelitian tentang coping strategy oleh Suryani (2006) menyimpulkan bahwa coping strategy informan dalam memecahkan masalah ekonomi keluarga yang dihadapi memanfaatkan aset kepemilikan, seperti mengembangkan keterampilan yang dimiliki, memanfaatkan sumber-sumber yang ada di lingkungan, serta memanfaatkan harta benda yang mereka miliki. Pekerja kontrak harus mampu memanfaatkan potensi yang ada dalam dirinya dan memanfaatkan sistem sumber di lingkungan dimana ia bekerja atau tinggal. Kurang mampunya pekerja kontrak dalam mencari dukungan sosial instrumental dijadikan pertimbangan usulan program dalam penelitian. Jika coping strategy dari diri sendiri sudah mampu dilakukan dengan baik, maka responden harus mampu meningkatkan coping strategy yang membutuhkan bantuan orang lain dalam pelaksanaannya. Hal ini dapat berpengaruh terhadap pengambilan tindakan dalam penanganan masalah, karena sudah sewajarnya bahwa setiap manusia membutuhkan bantuan orang lain dalam bentuk moril maupun materiil dalam kehidupannya.

Rencana yang dirumuskan untuk meningkatan upaya mencari dukungan sosial yang bersifat instrumental ini diarahkan kepada pemberian informasi-informasi dan strategi-strategi tentang penanganan permasalahan kebutuhan dasar dan statusnya sebagai pekerja kontrak dalam Program Peningkatan Dukungan Sosial Instrumental Pekerja Kontrak melalui Serikat Pekerja Tingkat Perusahaan (SPTP) di PT. Sanbe Farma Kota Cimahi. Pemecahan masalah yang dialami oleh pekerja kontrak harus didukung oleh lingkungan sekitar. Pekerja kontrak membutuhkan tempat berbagi keluh kesahnya 
untuk mendapatkan rasa ketenangan dalam menghadapi masalah kepada teman yang senasib yaitu sesama pekerja kontrak. Pekerja kontrak membutuhkan kelompok bantu diri (self help group) yang merupakan bagian dari Serikat Pekerja Tingkat Perusahaan (SPTP) di PT. Sanbe Farma Kota Cimahi.

Pengoptimalan kegiatan serikat pekerja untuk pekerja kontrak dilakukan untuk menjadi tempat berbagi cerita, pengalaman, informasi dan saling membantu memecahkan permasalahan yang dihadapi oleh pekerja kontrak. Hal ini dilakukan agar upaya mencari dukungan sosial instrumental dapat meningkat sehingga bisa dilakukan dengan baik dan optimal oleh pekerja kontrak. Rangkaian kegiatan yang dilakukan antara lain: (1) Komunikasi, Informasi dan Edukasi (KIE) tentang cara-cara mengakses dukungan sosial instrumental; (2) Komunikasi, Informasi dan Edukasi (KIE) tentang cara-cara dan strategistrategi dalam memenuhi kebutuhan dasar; (3) Diskusi kelompok dan berbagi pengalaman tentang upaya-upaya dalam mengakses pelayanan saat menghadapi permasalahan pemenuhan kebutuhan dasar; dan (4) Pembentukan kelompok bantu diri (self help group) bagi pekerja kontrak. Program tersebut telah melalui analisis kelayakan dengan menggunakan teknik SWOT (Strength, Weakness, Opportunities dan Threats) dan mendapatkan hasil bahwa program tersebut layak dilaksanakan untuk meningkatkan dukungan sosial instrumental pekerja kontrak di PT. Sanbe Farma.

Program ini diharapkan mampu meningkatkan upaya pekerja kontrak dalam mencari dukungan sosial yang bersifat instrumental, meningkatkan pengetahuan dan pemahaman pekerja kontrak tentang pemenuhan kebutuhan dasar, menguatkan kemampuan pekerja kontrak dalam mengatasi permasalahan dan meningkatkan solidaritas diantara sesama pekerja kontrak sehingga pekerja kontrak mampu memiliki coping strategy yang lebih baik lagi dalam memenuhi kebutuhan dasarnya.

\section{DAFTAR PUSTAKA}

Adi, Fahrudin. (2012). Pengantar Kesejahteraan Sosial. Bandung: PT. Refika Aditama.

Asri, Wijayanti. (2014). Hukum Ketenagakerjaan Pasca Reformasi. Jakarta: Sinar Grafika

Charles S. Carver, Jagdish L, \& Michael F. (1989). Journal Assessing Coping Strategies: A Theoritically Based Approach. Washington DC: American Psychological Association.

Chaplin, J.P.. (2014). Kamus Lengkap Psikologi. Jakarta: Rajagrafindo Persada.

Coyne, J., Aldwin, C., \& Lazarus, R. (1981). Journal Depression and Coping In Stressfull Episodes. Journal of Abnormal Psychology. Washington DC: American Psychological Association.

Diamira, Rahmadani. (2017). Coping Strategy Pekerja Outsourcing dalam memenuhi Kebutuhan Keluarga di PT. Perkebunan Nusantara IV Unit Adolina Sumatera Utara. Bandung: Sekolah Tinggi Kesejahteraan Sosial Bandung.

Doni, Judian. (2014). Tahukah Anda? Tentang Pekerja Tetap, Kontrak, Freelance, Outsourcing. Jakarta: Dunia Cerdas.

Edi, Suharto. (1997). Pembangunan, Kebijakan Sosial dan Pekerjaan Sosial: Spektrum Pemikiran. Bandung: Lembaga Studi Pembangunan STKS (2006) Pekerja Sosial di Dunia Industri:Memperkuat CSR. Cetakan Kedua. Bandung : Alfabeta.

Fauzi, Ihsan Jabir. (2017). Coping Strategi dalam Pemenuhan Kebutuhan Dasar Pemulung di Kelurahan Hegarmanah Kecamatan Cidadap Kota Bandung. Bandung: Sekolah Tinggi Kesejahteraan Sosial Bandung. 
Folkman, S., Lazarus, R.S., Gruen, R.J., \& Logis, A. (1984). Journal Appraisal, Coping, Health Status, and Psychological Symptoms. Journal of Personality and Social Psychology. New York: Spranger.

Garvin. (2011). Handbook of Social Work with Groups. Bandung: STKS Press (diterjemahkan oleh Herry Koswara, dkk).

Irawan, Soehartono. (2015). Metode Penelitian Sosial "Suatu Teknik Penelitian Bidang Kesejahteraan Sosial dan Ilmu Sosial Lainnya”. Bandung: PT. Remaja Rosdakarya

Keputusan Menteri Tenaga Kerja Dan Transmigrasi Republik Indonesia Nomor Kep. 100/Men/VI/2014 tentang Ketentuan Pelaksanaan Perjanjian Kerja Waktu Tertentu

Peraturan Menteri Ketenagakerjaan Nomor 44 Tahun 2015 tentang Penyelenggaraan Program Jaminan Kecelakaan Kerja dan Jaminan Kematian Bagi Pekerja Harian Lepas, Borongan, dan Perjanjian Kerja Waktu Tertentu Pada Sektor Usaha Jasa Konstruksi

Sugiyono. (2014). Metode Penelitian Kuantitatif, Kualitatif dan $R \& D$. Bandung: Alfabeta.

Suryani. (2006). Coping Strategi Orang Tua Tunggal dalam Memecahkan Masalah Sosial Ekonomi Keluarga di Desa Ngleri Kecamatan Playen Kabupaten Gunung Kidul Yogykarta Vol. Ed 188 No.30 Oktober. Jakarta: Media Informasi Penelitian Kesejahteraan Sosial Kementrian Sosial Republik Indonesia

Terok, L.I. (2015). Jurnal Hukum dan Masyarakat tentang Kajian Hukum Atas Hak Pekerja Kontrak yang Dikenai Pemutusan Hubungan Kerja (PHK) dalam Masa Kontrak. Universitas Sam Ratulangi Manado

Titik, Lestari. (2015). Kumpulan Teori Untuk Kajian Pustaka Penelitian Kesehatan. Yogyakarta: Muha Medika.

Triantoro S. \& Nofrans, E.S, (2009). Manajemen Emosi: Sebuah Panduan Cerdas Bagaimana Mengelola Emosi
Positif dalam Hidup Anda. Jakarta: PT. Bumi Aksara

Undang-Undang No. 13 Tahun 2003 tentang Ketenagakerjaan

Zastrow, Charles. (2014). Introduction to social work and social welfare. Edisi 11. USA:BROOKS/COLE.

\section{Internet}

Badan Pusat Statistik. Diakses dari https://www.bps.go.id/.

Kementerian Perencanaan Pembangunan Nasional (Bappenas). (2018). 2018, Jumlah Penduduk Indonesia Mencapai 265 Juta Jiwa. Diakses dari https://databoks.katadata.co.id/datapublish/ 2018/05/18/2018-jumlah-pendudukindonesia-mencapai-265-juta-jiwa.

Rieke Diah Pitaloka, dkk. (2015). Survei Pengupahan Nasional Rekomendasikan Kenaikan Upah 2016 di 7 Kawasan Industri Sebesar 33\%. Diakses dari http://www.rumahdiahpitaloka.org/surveipengupahan-nasional-rekomendasikankenaikan-upah-2016-di-7-kawasanindustri-sebesar-33/ 